\title{
2016 United States of America'spresidential Election: Reasons Why Donald Trump Won
}

\author{
Odoh Patrick Abutu, Salisu Abubakar \\ ${ }^{I}$ Department of Public Administration The Federal Polytechnic P.M.B 1012 Kaura Namoda Zamfara State, \\ Nigeria West Africa \\ ${ }^{2}$ Registry Department The Federal Polytechnic P.M.B 1012 Kaura Namoda Zamfara State, Nigeria West Africa
}

\begin{abstract}
The 2016 United States Presidential Election came on the $8^{\text {th }}$ November and gone with Donald Trump haven been declared as 'President Elect" and has assumed office on the $20^{\text {th }}$ January 2017 as the $45^{\text {th }}$ President of the United States of America . Donald Trump's victory during the primary election of Republican Party and the U.S presidential election from nowhere continue to beat the imagination of people globally. This study was carried out using qualitative content analysis and relied heavily on the texts from social media network comments as well as on print/electronic media publications. These includes twitter, facebook, radio and television and cable news, documentary sources of available literatures which were used to provide answer to the surprising ongoing question of "how Donald Trump did became President-elect in the United States of America from nowhere? In the concluding remarks, the paper based on strong findings from the literature texts consulted, tenaciously holds that Donald Trump's victory in the 2016 United States Presidential election is reliably attributable to his stern promises to make America great again coupled with the overwhelming support he got from the white voters as well as his undeniable wide coverage of campaign and his selection by the United States Electoral College based on merit amongst other factors
\end{abstract}

Keywords: United States, presidential election, reasons why Donald Trump won

\section{Introduction}

Elections as the blood stream of democracy have undeniably become the best alternative instrument of producing leaders and peoples' representatives in our global world. Different types of elections are conducted by different countries yearly and through it many had won political positions and form government while at the same time many have lost and do not form government..In the United States of America comprising fifty (50) states, elections took place on the $8^{\text {th }}$ November, 2016 but of particular interest was the Presidential election which Donald Trump was declared as the $45^{\text {th }}$ President-elect at the conclusion and announcement of the Presidential elections result and he was subsequently sworn-in as the United States of America President on the $20^{\text {th }}$ January, 2017.

While Donald Trump polled 61,201,031 going by popular votes, the popular vote of Hillary Clinton was 62, 523, 121 indicating that Hillary Clinton beat Donald Trump by 1,322,090 votes (Politico Magazine, 2016). However, Hillary Clinton lost to Donald trump in the U.S 2016 Presidential elections. To those who do not have the knowledge of additional conditions and the intricacies involved in the processes of election in different countries, the picture of the victory of Donald Trump in the 2016 US Presidential election looks gloomy and it seems to have been painted black. However, it is pertinent to note that when it comes to election based on the exigencies in a country and which America is not an exception, different countries have different democratic criteria apart from the majority vote and minority rights that is the commonly known and the strongest pillar of democracy.

According to American electoral rules, a presidential candidates must not just win the majority vote or what is referred to in America as "popular vote" but needed a must win of a minimum votes in 270 out of the 538 "electoral colleges". Though, the focus of this study is not on Electoral College, for the sake of academic clarification, we need to briefly explain what the 'Electoral College' in U.S mean. The Electoral College in U.S is not a college where academic progtamme is being run but, it is a politically powerful institution of persons other than the popular voters empowered by the United States of American Constitution. This is contained under Article II Section 1 and some other sections in $12^{\text {th }}, 14^{\text {th }}, 15^{\text {th }}, 19^{\text {th }}, 20^{\text {th }}, 22^{\text {nd }}, 23^{\text {rd }}, 24^{\text {th }}, 25^{\text {th }}$, and $26^{\text {th }}$ Amendments (US Constitution in US Electoral College ) respectively. The 'Electoral College' is empowered by the Constitution to vote for a presidential candidate of their choice under the auspices of the United States of American Congress. The presidential aspirant with the highest number of the Electoral College votes in his or her favour becomes the president elect not minding his or her popular vote. This means that the US Presidential aspirants use two different constituencies at the same time for election. In other words, it mean that the presidential candidates are elected by two separate set of qualified and enfranchised electorates (voters) namely the popular voters within the United States and the members of the Electoral College under the Congress (the 
highest legislative institution in the U.S) and the voters votes almost at the same time but at different polling units. The Electoral College is made up of 538 (US Electoral College) Electoral Colleges within the Federation of United States and the membership is not uniform and equal for all the states in America Federation. The membership is determined by the number of the delegation in the Congress. In the game of the politico-electoral College vote, if a candidate win more of those states with many numbers of electoral colleges, the candidate stands as a tower over the other candidate (s) to win the presidential tickets. In view of this, it is very possible for a presidential candidate to win the popular votes but will lose to the opponent if his opponents win the 'Electoral College' votes. This is the game that saw Donald Trump through to victory as President of the United States of America. He won states with more electoral votes than Hillary and the other two Presidential Candidates, in fact he scored 306 votes in the 'Electoral College' By implication therefore, the decision of the Electoral College constitutionally supersedes that of the popular voters and it is based on that that Donald Trump who polled 1,322, 090 popular votes less than Hillary Clinton was declared the winner of the US 2016 Presidential election. Despite the above, did Donald Trump win the 2016 U.S Presidential election? Yes of course, he won.

Based on the Presidential election results on state by state basis, Trump won more states than the other Presidential Candidates. The results from the states shows that Trump gallantly defeated the other three presidential candidates namely Clinton, Johnson and Stein. The states he won according to Politico Magazine (2016) includes Alabama (62.9\%), Alaska (52.9\%), Arizona (49.5\%), Arkansas (60.4\%), Florida (49.1\%), Georgia (51.3\%), Idaho (59.2\%), Indiana (57.2\%), Iowa (51.8\%), Kansas (57.2\%), Kentucky (62.5\%), Louisiana (58.1\%), Michigan (47.6\%), Mississippi (58.3\%), Missouri (57.1\%), Montana (56.5\%). Nebraska (60.3\%), North Carolina (50.5\%), North Dakota (64.1\%), Ohio (52.1\%), Oklahoma ()65.3\%), Pennsylvania (48.8\%), South Carolina (54.9\%), South Dakota (61.5\%), Tennessee (61.1\%), Texas (52.6), Utah (45.9\%), West Verginia (68.7\%), Wisconsin (47.9\%), Wyoming (70.1).

In all, Donald Trump won in thirty states as against the twenty states won by Hillary Clinton, the strongest revival in the 2016 U.S Presidential race. Trump even won New York, his home state and Clinton's. Apart from winning the presidential ticket, his overall performance in the election is reflective of national outlook (meaning that the votes he received from the election was widely or nationally spread) more than any other presidential candidates including Hillary Clinton.

\section{The Need for the Study}

Though, many persons have written stories mostly in the social media networks such as facebook, tweeter, and in others justifying the reasons for Donald Trump's presidential election victory or the justification for Hillary Clinton's and other two aspirants' presidential election lost in the 2016 United States of American general elections, there is still much gap created by the scanty academic study and academic analysis of the 2016 presidential election in the U.S from the scholarly academic point of view. Hence, the urgent need for applying qualitative content analysis using the social media networks comments as well as information from the prints and electronic media including newspapers, magazines and radio, television, cables to studying the 2016 U.S Presidential election from the academic point of stand. The study will academically prove why Donald Trump won the election and why the other three presidential candidates lost the election most essentially so as to clarify those who protested the outcome (2016 U.S Presidential results) of the election immediately the winner of the presidential ticket was declared.

\section{Methodology}

The methodology adopted for this study is twofold. For the source of data, the secondary method is adopted while for data collection and data analysis/interpretation, qualitative content analysis was used accordingly. And the content that is analyzed in the study is social networks and the media. Why adopting the method and in particular, the use of social networks and the media not another methods? Because in the first instance, qualitative content analysis is an accepted method of systematic analysis of texts and it was developed and used in 1980s (20 years ago) according to Mayring $(1983,2000)$ to study longitudinal psycho social effects of unemployment (Ulich, Hausser, Mayring et al, (1985) in Mayring (2000). secondly, the media was chosen for the study because, the media such as televisions, Radio, and Cable has in recent years transform the audience scale and consequently has impacted the social and political culture of the country, United States (Read, 2016). Besides, the social media as well as the prints and electronic media is the most commonly used methods of communication and it is most widely coverage of disseminating information in the world today. More importantly, the unavoidable use of social media is pitched on the truth that forty four (44\%) percent of adults living in the U.S read their news from facebook (Read, 2016) and Facebook appeals to teenagers, especially Macedonia teenagers who extensively used the Facebook to campaign for Donald Trump (Read, 2016) and at the same time let the researchers add that the social media was negatively used to discredit Hillary Clinton in the 2016 U.S Presidential election as we could see later in this study. The above reasons therefore, academically 
empowered the researchers to adopt the above methodology to carry out the study accordingly. Once more, social media globally is the fastest, quickest and most widely means of communication today. Finally, the use of the above methodology for this study is premised on the fact that the researchers of this study do not live in the United States of America neither did they participate in the 2016 U.S presidential election under study as voters or observers. Therefore, it was not feasible to use other methods of collecting and analyzing data even though, it could have been possible coupled with the fact that it has been proved that data collected through qualitative instrument of content analysis documents are rich and could be used for research because it contains recorded and already transcribed communication obtained from discourses, observations, interviews, documents, video tapes, audio tapes, documents (Mayring, 2000).

\section{Factors that facilitated the Victory of Trump in 2016 U.S Presidential Election Here is one thing we know: Donald Trump against all odds, will be the next President of the United States (CNN, 2016) and he actually became the U.S President on the $20^{\text {th }}$ January, 2017.}

Trump's remarkable win in the 2016 election is amazing surprise to most political analysts and institutions of election prediction in the United States and elsewhere because even on the day of election, the pre-election polls still indicated that Hillary Clinton will win by $85 \%$ as against $15 \%$ for Donald Trump (Katz (2016). Summary of texts from Guaghan (2016) in the Quartz also submits that "in one of the biggest upsets in American political history, Donald Trump won a truly historic victory in the US Presidential election". Guaghan (2016) further asserts that Trump before the election consistently had the unfavourable rating that no nominee of any major political party ever have in the history of United States politics. This was due to the assassination of his character and integrity by the Hollywood video tape, extreme lewd conversation about women (Fahrenthold, (2016) coupled with the quantum number of women that came out openly and accused Trump for sexual harassment. Before the election, Nationwide polling averagely scored Hillary Clinton a lead in 3 point overall while she would win a minimum of 300 Electoral College votes based on the rating of the state-by-state polls (Gaughan, 2016).

Generally, Trump was not considered to be any political force against Hillary Clinton because he has never been a politician, never held any political post neither was he a recognized political figure in the United State unlike Hillary Clinton who have grown politically in the United States politics, have held several top political positions and she is a woman of substance in all political endeavours. She pulled a crowd of all well known democratic politicians in the U.S and all indicators showed that she has become a United States of American President but only waiting for a ceremonial passage through the election on the $8^{\text {th }}$ November, 2016.

Dramatically however, despite the negative allegations leveled against Trump capable of damaging his political and electoral integrity and reputation, coupled with Hillary Clinton's political tower and storm around Trump, he gallantly defiled the entire allegation in his historic vote particularly in Florida and Ohio States which invariably earned him the required minimum of 270 Electoral College votes that saw and soared him through to victory. He swept victoriously through the country unhindered by any obstacle along the road to electoral victory capturing according to Gaughan, (2016) Atlantic Coast to the Rocky Mountains of Wisconsin, Pennsylvania, Iowa and Michigan.Several reasons have contributed to the surprising emergence of Donald trump in the 2016 United States Presidential election contest. In the presentation of the factors responsible for the triumph of Trump, the media and the social networks arguments shall be presented interchangeable not sequentially by discussing only media analysis first or the social network first. It will be interchange as the analysis proceeds. The role played by the Federal Bureau of Investigation (FBI) under its Director, James B. Comey cannot be overlooked in the discussion of the 2016 U.S Presidential election victory of Donald Trump and the failure of Hillary Clinton. On the 28 October, 2016, eleven (11) days to the Presidential election, FBI reopens for further investigation Hillary Clinton email case which was earlier suspended by the same FBI while Comey in July 2016 testified under the Oath before the US House Committee that FBI finished investigating email matter of Hillary Clinton and there would be no criminal charges (Horwitz, 2016). Comey's Letter to FBI employee relating to the revisit of the Hillary Clinton email investigation reads as follows:

This morning I sent a letter to Congress in connection with the Secretary Clinton email investigation. Yesterday, the investigative team briefed me on their recommendation with respect to seeking access to emails that have recently been found in unrelated case. Because those emails appear to be pertinent to our investigation, I agreed that we should take appropriate steps to obtain and review them.

Though, Hillary was still cleared by FBI after about four days to the election, Gaughan (2016) said, the presidential election results shows that the email saga against Hillary caused damage through the deflation of her presidential ambition.Guaghan (2016) also has presented striking facts to show another side of Trump's presidential electoral victory. He said that Trump is a highly recognized figure for over thirty years which by implication mean that he is highly recognized very well before he came out to vie for the presidency. He has been a celebrity for long and that the media rallied round him which a study found out that as at May, 2016, US $\$ 3$ billion has been received by Trump as a free advertisement from the media coverage of Trump campaign. 
He (Guaghan, 2016) in continuation of discussion further added that the Trump like Ronald Regan had highly motivated voters and his civility and basic standards of decency coupled with his highly motivated voters earned him his victory. In fact, trump presidential electoral victory and Hillary vanquish of the presidential election is an indication that politicians and political figures is not a match to a well celebrated figure in the society when it comes to election. The centrality of the message of Trump to Americans from the campaign right from day one to the last day of campaign was a clear laudable and noiseless and a well-filtered one. It centered on immigration and trade as Guaghan (2016) identified. The message catch the glimpse of the Americans particularly the white working class voters and the focus on immigration and trade as asserts by Guaghan (2016) paid off in spades on Election Day very reasonably.

Professor Guaghan acknowledged that though, Trump had no experience in elective positions or political appointment which is similar to Dwight Eisenhower in the 1950's (though Eisenhower served during the World War II in Europe as Supreme Commander) Trump won the presidential election. The rational question is why the voters did select Trump not Clinton? The answer was Americans wanted a change from rules of the political elites to a non-political, neutral person because Guaghan (2016) noted Americans believed that the nation was wrongly directed by the political class under Obama hence, the need for a change. The clear and clean message of Trump during the campaign convinced the electorates beyond reasonable doubt that he will bring the needed change because he repeatedly emphasized and re-emphasized what he said he will do anywhere he went throughout the campaign period.

Trump as justified by Guaghan (2016), capitalized on the cream of political experience of his strongest rival in the presidential race, Hillary Clinton to convince his voters that she is only representing the status-quo not for any positive change and the voters keeps that to mind as a token they used to vote for Trump.

Guaghan (2016) in his final submission on reasons why Trump win reveals that Trump strategized along divisive tendencies among the Americans and the 2016 election clearly indicated that Americans is a divided characters with respect to race, class, culture and gender.Kreig's (2016) outlines in CNN Politics "How did Trump Win? Here are 24 Theories" was also captioned by different media's and other social networks such as Kenya News, KMC News, World News etc. Kreig (2016) provides 24 reasons which he called theories to provide analytical explanation for the glorious triumph of Trump over Hillary Clinton and two others in the United States of American 2016 Presidential election race. These include:The influence and roles played by facebook. Facebook comments were extensively used in favour of Trump by teenagers to assassinate the character of the strongest opposition candidate (Hillary Clinton) in favour of Trump. Some of the negative facebook comments allegation against Hillary Clinton include captions such as "the Pope has endorsed Trump, Hillary Clinton allegedly bought US\$137 million illegal arms, in Maldives, Hillary Clinton bought US\$200 million house (Reads, 2016). Apart from these, there are several other facebook messages posted to bring down Hillary Clinton which unfortunately may have been exaggerated far below the line of truth, stories that may not in any way be correct or have a proof.

Social media contributed immensely to the triumph of Trump. “...Trump won because of social media" (Watson, 2016). In the social media, millions and thousands of campaign messages were done for trump by different people as well as Trumps organizations which super cedes all the other presidential candidates. It has been argued that Donald Trump victory could be credited to and be explained from the overwhelming turnout of voters in his favour as against the low turnout of the democratic voters for Hillary Clinton. This evidence is shown in several sources of social media. The social media sources proved that Democratic presidential candidate (Obama) in 2008 scored 69, 498, 516 (52\%) percent while the Republican (John McCain) polled 59,948,323 (45.7\%). In 2012, Democrat presidential candidate (Obama) scored 65,915,795 (51.1\%), Republican Presidential candidate (Mitt Romney) have 60,933,504 (47.2\%). The Presidential election results of 2016 for Democrat candidate Hillary Clinton was 59,861,516 (47.7\%) while popular vote for Republican Donald Trump was 59,639,462 representing 47.5\% (Imgur, 2016). The above analysis is represented in the chart below.

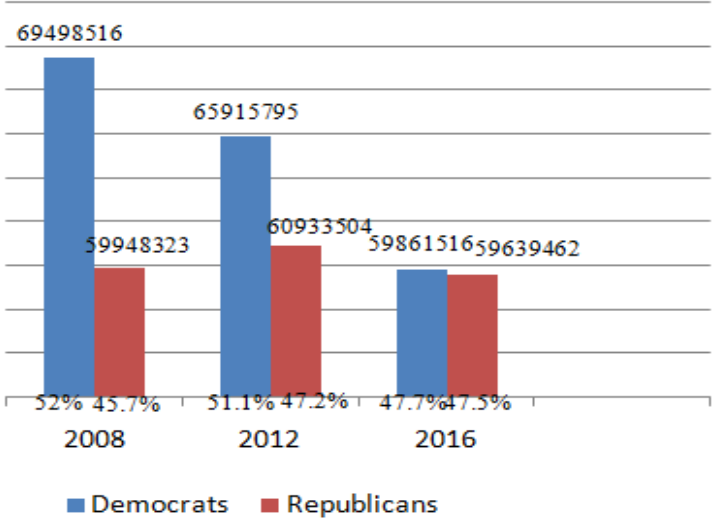

Figur 1. Comparing Voters Turnout in US Elections in 2008, 2012 and 2016. 
Imgur (2016). I made a Chart showing the popular votes turn out in 2008, 2012 and 2016. Available online at http://imgur.com/TOGIbcP From the chart above, if the 2016 presidential election performance of the Democratic Party is compared with its performance in the 2008 and 2012 presidential election, it is visible and clear that Democrat Party abysmally perform badly in the 2016 Presidential election. While in 2008, the Democrat Party stands like a tower above the Republican Party, the height of the Democrat was reduced drastically as against the rising height of the Republican Party in 2012. In the 2016 presidential race, the ever continuing growing Republican Party caught up with the continuous dwarfing Democrat Party from 2008 in height. This development is what gave Donald Trump an edge over Hillary Clinton in the 2016 U.S Presidential race. Amazingly, Hillary Clinton, a woman among women in the United States of American and a world-wide known woman was rejected at the poll by her fellow white sisters' as they decided to vote massively for Donald Trump, Hillary's strongest male counterpart in the 2016 Presidential election race. It has been reported that fifty three percent (53\%) out of the total white females that voted for various presidential candidates in the 2016 US Presidential election voted for Donald Trump. It is surprising and outrageous for such high percentage of White female votes that went in favour of Donald Trump because Trump bragged about committing sexual assault on tape...undo legislation that has afforded health insurance...spent 30 plus years on the public eye reducing women to their sexual attributes...(Anderson, 2016). Though, the justification for the white women going for Donald Trump in the 2016 presidential election may lie in the fact that the white women prefer to align with the position that will promote white people more than just any other factors which others may seem to have been the best criteria for the vote for other candidates other than Trump.

In the 2016 US Presidential election, Donald Trump pulled through the crowd of the white to capture political power winning the most prestigious seat in the world-the US President. Sources available indicates that the white women and men put together gave fifty eight percent (58\%) of their votes to Trump while the white men that voted for Trump was sixty three percent (63\%). Also, $49 \%$ of the college graduates voted for Trump (Potts, 2016). From the analysis in the above two paragraphs, the whites across board massively voted for Donald Trump in the 2016 US Presidential election. The significant thing to note from Trump's victory relating to the massive vote by the whites a source contends, is to end and avoid further extension of the "last eight years of one demographically symbolic President..."(Wayne, 2015 in Potts, 2016). The eight years referred to here is the eight years of black Obama regime in America. The White voters voted for Trump as against Hillary because Hillary's winning will be an extension, elongation and encouragement of another indirect black and other races ruling in America through the White Hillary. Trump in his campaign has repeatedly and clearly appealed to his voters about the situation of the economy in the United States of America caused by a prevailing black Obama regime. Therefore, the White's votes for white Trump is to stop black corruption under the black Obama regime. David Frum according to Potts (2016), compiled all the interview he had with Trump voters in July 2016 which portrayed that Obama's regime is humiliating and that Hillary's regime will be worse if she wins. Indeed, racial campaign earned Trump the most powerful world position-The US President. This Potts (2016) stressed that there is more important racial identification in the campaign and subsequent victory of Trump and that anyone who says otherwise just stretched to deny what the raw numbers show where men were more likely to vote for Trump, and so were white people. This simplest explanation according to Potts (2016) is the right one.

It has been openly proved by Russia that it has hand in the campaign and success of Donald Trump in the US 2016 Presidential election. Though, during the campaign period, there are several allegations against Russia pointing accusing finger to her that she have hand in the campaign of Donald Trump particularly on the role of kremblin in the bitter race against Hillary Clinton by the President elect. The allegations then were denied both by the Trump Spokesman, Trump himself and even the Russia President, Vladimir Putin over the involvement of Russia in the campaign of Donald Trump. However, available source from Russian Deputy Foreign Minister, Sergei Ryabkov in an interview with the State run Interfex news agency has revealed the involvement of Russia in the Donald Trump Presidential electoral victory as it appears in "The Washington Post" of $10^{\text {th }}$ November, 2016. This has nullified any earlier denials of the Trump's Spokesman, Hope Hicks before the election was conducted on Tuesday $\left(8^{\text {th }}\right.$ November, 2016) that Trump campaign had no contact with Russian officials (Filipov \& Roth, 2016). However, all that Trump needed then is to win the election and he did denied Russia involvement in his campaign just to win and he did won. That is game of politics which has nothing to do with righteousness, honesty and sincereity.

It has been argued by Lerner (2016) that one among the reasons for the unimaginable victory of Donald Trump in the 2016 US Presidential election is the shaming of Donald Trump's supporters during the campaign by the leftists namely the "African-Americans, feminists, immigrants, Muslims, Jews, liberals, progressives..." (Lerner, 2016). The rights (whites) were able to successfully persuaded the white working class people into believing that their vulnerability is due to the selfishness of the leftists not necessarily because they themselves has failed (Lerner, 2016). Coupled with the above is also the fact that the whites believed they were being blamed for the slavery and genocide that the leftists are suffering therefore, the whites who are supporters of 
Trump feels they are facing unfair reality, ignored the racism, xenophobia and the likes used by Donald Trump in his campaign and massively threw their weight on Donald Trump at the poll on the $8^{\text {th }}$ November, 2016 which saw him through to victory.Based on comments from social media, most of the rural mid westerners on the day of election did not come out to exercise their civic rights by voting for any candidates even though, it would have been likely that those group of voters would have go for Hillary Clinton.

The victory of Trump over Hillary in the 2016 US Presidential was not unconnected to negligence on the part of the Democratic Party as revealed by Krystall (2016). Krystall Ball is a Democratic Congressional Candidate. He outlined some of the possible neglects or carelessness that led to the crashed out of the Democratic Party under which Hillary Clinton contested in the November 2016 US Presidential election. The reasons built up over time from 2010 though, not without notice to the Democratic Party. The Democratic Government under Obama from 2008 to $8^{\text {th }}$ November, 2016 failed to tackle the economic woes which led to the demise of "coal mines, the closure of steel mills, drugs becoming rampant, the towns are decimated, and everywhere you look depression, despair, fear...(Ball, 2016) before the Presidential election was held. Ball (2016) further revealed that Democratic Party campaign for the number 1 seat in America was not a match for Trump's vibrant, clear and intimidating campaign with its appeal for a promised white nationalism coupled with message for protection against competing with black and brown people. Though, Trump campaign looks like a weak campaign strategy anyway but, indeed it was better, stronger and transmitted a convincing message to the white Americans contrary to Clinton's campaign message which has no strong element as what she intends to do for the towns.

Trumps may have been taken for granted y the Democrat party on the bases of his lack of experience in public administration, governance and complete novice in politics when compared with Hillary Clinton, a woman of political and administrative substance, a woman of reputable qualities, a woman of global acceptance, a woman that is highly respected in America for her cream of expertise and leadership tower. Surprisingly after the Electoral College votes Trump proved to Clinton and her Democratic Party that political experience never counts in winning a democratic seat through election but it is how best the contestants play their game during the electioneering campaign that transform into the winning number of votes on election day. In a related development, Kentucky democrats, Ball (2016) submits, lost by 10 points on Election Day in 2010. The Republicans reclaimed the House back in 2010, take over the senate in 2014, and 24 states are fully in control of the Republican Party at House, Senate and gubernatorial levels and finally, Kentucky State house was handed over to the Republican. Ball contended that despite the gradual lost of all these seats to the Republican in the vast middle, south and mid west of the country, Democrats seems not to care provided it controlled the President at the centre. Based on this development, Republican Party eventually out-ran the democrats in 2016 and now has the President and majority of members in the Congress.

Ball (2016) also lamented and blamed the Democratic Party for paving the way for Trump to win the 2016 US Presidential election. How? Because the Democratic Party played a political game which eventually resulted in the selection of Hillary Clinton instead of Bernie Sanders which would have led to a different outcome at the presidential election poll. Hillary is not strong enough to withstand the economic and social and celebrity popularity of Trump. The National Committee of the Democratic Party also have a share of blame in the defeat of the Democratic Party Candidate, Hillary Clinton by Donald Trump in the November 8, 2016 US Presidential election. The National Committee of the Party as some has argued failed to select other candidates other than Hillary Clinton. The selection process was politicized, biased and based on certain hidden issues. A different person particularly Sanders, other than Hillary Clinton would have made a different mark against Donald Trump gallant victory. "by biasing its internal electoral market the DNC (National Committee of the Democratic) selected the less competitive candidate defeating the purpose of running a primary (Wikileaks on twitter).

Trump's Victory in the 2016 election is linked to the votes he secured from the millenials and the young voters. It has been alleged that many young voters decided to go for Trump instead of Hillary (Mohan, 2016). The likely reasons that could be established for the young people who went for Trump may be for the same reason of Trump promising to restore back the lost glory in the United States coupled with the fact that Trump campaign was more vibrant coupled with the unchallenging fact that Trump carried the younger generations in U.S along in his campaign than Hillary Clinton.Bolton's (20116 in Kreig 2016) made a useful contribution to the increasing argument behind Trump Victory. Major substance in John Bolton (a former UN Ambassador) led argument is that there are group of Democrat voters called the "Reagan Democrats" who are made up of working class of the white voters. They lean on Democrats in most political engagements but sometime could shift base to vote for a special candidate from another political party. They voted in this manner during the time of Ronald Reagan and they did it again for Trump in the November, 2016 Presidential election which invariably gave Trump a hedge ahead of Hillary A calculation made to interpret the victory of Donald Trump by Nguyen (2016) is hinged on high probability that the two Presidential candidates namely Johnson Gary, the Presidential candidates for Libertarian Party and the Presidential candidate for Green Party, Jill Stein 
may have indirectly assisted Donald Trump to win the election. How? On the premise that some of the supporters of the two less popular parties who refused voting for them after all may have switched over to Donald Trump and also to Hillary Clinton. However, there are the tendencies that the percentage of those who may have switched over to Trump instead of Hillary may be numerically higher. The category of the likely decamped to either of the two strongest presidential candidates are one, those who said "Fuck Gary Johnson" and two, those who said "Oh, And fuck Jill Stein too".

One other explanation offered relating to the surrounding Donald awesome victory over Clinton offered by Nguyen (2016) is that voters from Latino, Africa-America and the democrats who are supposed to massively come out and vote for Clinton or more appropriately vote against Trump did not do so and therefore, Trump supporters capitalized on that weakness or omission to vote Trump through. Secondly, Nguyen (2016) further opined that the $3 \%$ popular votes as well as the over four million votes scored by the Libertarian Party are within the close range of the states that Clinton would have secured. Clinton lost 4,000 votes where Johnson scored 25,000 votes in New Hamshire. The Green Party whose Presidential candidate is Stein scored 51,444 votes in Michigan while Clinton lost 12,686. Also, in Wisconsin, Stein received about 1 percent vote. Without Stein, the voters would have switched to Clinton. This probable situation ran through many other places. Though, Nguyen probability postulation is not based on any founded scientific experiment, the Researchers cannot rule out Nguyen's probable postulation that those probability would have occurred and Hillary Clinton would have secure a winning chances of vote as he claim, it is the absolute belief of the Researchers too that the same probable situation would have go for Trump too by winning in those areas and as such Nguyen is biased in the application of the probability judgment because after all no scientific evidence to show that those voters intended to vote for Clinton before they change their mind and voted for Johnson and Stein.

Apart from the reasons so far adduced for the victory of Donald Trump, Soave (2016) in his own investigation identified one other important reason. He Soave (2016) claimed that Donald Trump beyond reasonable doubt was able to convinced higher percentage of Americans (particularly the whites) that he will certainly destroy the so-called political correctness that has been instituted over the years where a far-leftists (African-Americans, feminists, immigrants, Muslims, Jews, liberals, progressives...”, Lerner, 2016) has captured and arrogated to themselves institutional power and have been using the opportunity to punish people (possibly the whites). Trump's (now US President effective $20^{\text {th }}$ January, 2016) view of anti-political correctness is very popular among college students and at several occasions, students in various institutions of higher learning became apostles of Trump anti-political correctness such as "....... Rutgers university students event, throngs of students erupted into cheers of a Trump! Trump! Trump!". Students have acted the play on anti-political correctness which Soave (2016) said "I have watched this play out on campus and after campus". Radio host, Cardillo (2016) has also strongly agreed that Donald Trump's victory in the 2016 Presidential election in US was facilitated and enhanced by his ability to carefully listen to the Americans. Trump ignored what the "Process" demands and decided to go for what the Americans demanded and wanted and agreed to base his policies on that. He (Trump) decided against following the elites and the political class and big wigs to gain political power rather he settled for the Americans themselves to make him president. According to Cordillo (2016) "those inside 'The Process' did all they could to destroy Trump, but the American voters simply wasn't having it".

Hayes in Camosy (2016) presented a differing side of argument over the contending reasons for the victory of Donald Trump. Hayes in his submission has argued that Trump's victory in the 2016 US Presidential election is not all about racism as several people tend to believe because the leftists voted for him. He (Hayes) proved in his argument that twenty nine percent (29\%) of Latino voters voted for Trump while he also received a higher percentage of African American votes than what Romney got in 2012 Presidential election. Hayes maintained that the reason that led Trump to victory was that both the men and women American voters (whites in particular) opted to vote for Trump and rejected Hillary Clinton because they disliked Clinton even more than they disliked Trump. Therefore, they felt that instead of voting for Clinton let them vote for Trump. Hayes (2016) finally summed up his protest by saying that anyone who said the leftists did not vote for Trump is an understatement that lacks any substance of scientific proof since the votes are there for anyone to see.

Krakauser (2016) disagreed with all reasons given by the previous school of thoughts on the explanation of the reasons for the triumph of Trump in the 2016 Presidential election in the United States of America as given above. The main thrust of Krakauser (2016) position on why Trump won is a display of portrait picture of the image of the present ruling Democratic Party Government in the Washington. He contends that the failure of Hillary Clinton is an indication that the Government has failed the people, the people has lost confidence in the "Democrats" leadership in America, people are no more having confidence on the "Democratic Party" Government in US, and finally, the people saw that giving another mandate to a Democrats candidate to steer the nation of America again this time will further bring more sorrow to them. Krakauser (2016) further reiterated that Trump won because of his relational attitude with people just like other past American Presidents like Bill Clinton, George W. Bush, Obama and that Hillary Clinton lacks this "secret 
ingredients" according. Krakauser (2016) summed up his position on the reasons for Donald Trump victory saying "But for the large portion of the 50+ million Americans who cast their votes for Donald Trump..., they did so to send Washington a message. Wrapping that message in gender or race or any other biases misses the point".In a related development, very important and central destroyer of the image, integrity and personality of Hillary Clinton that led to her Presidential Electoral lost to Donald Trump at the poll was the corruption allegation leveled against Hillary Clinton and the Obama-led government of US by Donald Trump during his campaign. Trump said:

Hillary Clinton May be the most corrupt person ever to seek the presidency", I know that corruption has reached a level like never ever before in our country, I want the entire corrupt Washington establishment to hear the words we areabout to say: when we win... we are going to drain the swamp (Barrington, 2016)

The above is one of the Donald Trump's campaign slogans while gunning for the presidency in 2016 captured by the "The Telegraph" of UK in its edition of November $9^{\text {th }}, 2016$ while contributing to the reasons for Trump's victory in the 2016 US Presidential election. The above proclamation made by Trump went a long way to discourage voters including even some of the Democrats from voting for Hillary Clinton on the $8^{\text {th }}$ November, 2016 during the US Presidential election as supported by Thiessen (2016) who claimed that "she (Hillary Clinton) lost because exit polls showed that 54 percent of voters believed that she is corrupt". Trump throughout his campaign declared that his regime if voted into power is going to be a corrective regime that will put a stop to the on-going corruption instituted in America by the regime of the Democrats under President Obama and to make America great again.

Once again, the demarcation between Donald Trump and Hillary Clinton that saw Trump through to defeat Hillary at the poll was his constant promise to remember the forgotten Americans (the working class). Trump consistently promised them in strong term to actualize and do what he said when he become President of US. Hillary Clinton as Talukdar (2016) put it, on the other hand has a campaign train that was surrounded by Beyonce and Jay-Z, Lady Ga-Ga and Ben Affleck, the billions and the entire Hollywood who Clinton wave hand at and they in response, wave back at her. There was no soul steering message from Hillary to thirsty and yearning Americans who are waiting for new thing out of the Hillary who wants to go to the "White House" other than the characteristics of the promotion of the existing status-quo. "Ironically, this tendency to reach out and talk to only those with who we are most comfortable has been exacerbated by the vote-targeting tools developed..."(Katz, 2016). This eventually contributed to the collapse of Hillary Clinton Victory at the poll.

\section{Findings}

Based on existing available documents before the Researchers and used by them to undertake this study has shown that General election was held in the states of the United States of America on November 8, 2016 and that Presidential Election was among the elections held. Also, evidences from sources shows that four Presidential Candidates namely Hillary Clinton of the Democratic Party, Donald Trump of the Republican Party, Johnson Gary for Libertarian Party and Jill Stein for Green Party respectively contested the 2016 Presidential election in United States of American. It is also a scientific fact as proved by our study that the strongest presidential candidates in the 2016 Presidential Election in United States of America are Hillary Clinton and Donald Trump and it is their names that dominated all the pages of the Medias and the social Medias we reviewed.

Scientific facts from the study also claimed that the four Presidential Candidates contested the Presidential Election on the $8^{\text {th }}$ of November, 2016 and that the results of the Presidential election were declared accordingly and the winner of the Presidential election is Donald Trump through the 306 Electoral College votes he obtained far higher than the 270 minimum Electoral College votes set by the Constitution. However, Hillary Clinton came second best in the election because she won by popular votes with a score of $62,523,121$ as against 61,201,031 scored by Donald Trump. The popular vote result margin between Clinton and Trump is 1,322,090. Donald Trump victory in the election triggered surprises and reactions which include post-Presidential electoral violence and comments as to the reasons why Trump won the election. In this study, the focus of the Researchers is purely explanatory of the reasons of election victory of Donald Trump in the 2016 Presidential election in the United States based on different explanations offered by many institutions, organizations and individuals. The Researchers in this work articulated, coordinated, assembled and integrated together the diversified views of the people into academic interpretation and analysis using the methodology (Qualitative content analysis which the instruments for data collection is secondary documents including prints and electronic media as well as social networks).

The findings from the review and analysis based on the available previous literature documents reveals that Donald Trump's electoral victory over the other three presidential candidates particularly, Hillary Clinton in the 2016 Presidential election in the United States of America are in many folds. The chiefs among the striking factors are: the corruption allegation openly leveled against Hillary Clinton and the immediate past incumbent Government of the Democratic Party being led by Barrack Obama from January 2008 to January 2016 which 
the exit poll shows is true as represented by fifty four percent (54\%) of voters who say they didn't vote for Clinton because she is corrupt. Secondly, the email saga against Hillary Clinton and the revisit of the further investigation of same email case by the Federal Bureau of Investigation (FBI) when it was eleven (11) days to the Presidential election. Three, the unbeatable wide coverage of Trump campaign train into the nooks and crannies of America states, counties and sub-urban areas proclaiming to make America great again, four, Trump's message of hope to American voters that he will correct and demolish the so-called political correctness where the white Americans and the leftists Americans are placed at par.

Others are inability of Democratic voters to come out to vote in the 2016 Presidential election as the case with the 2008, 2012 presidential elections coupled with the fact that there was a general low turnout of voters in the 2016 general elections, the great role played by Russia in the Trump campaign as revealed by the Russia Deputy Foreign Minister almost immediately after the Presidential election result was declared, the mistake made by the Democratic Party for selecting Hillary Clinton in its primary election,

Finally, some other factors include rejection of Hillary Clinton by both the American white men and women at the poll, the carelessness on the part of the Democratic Party to check the activities of the Republican Party from 2010 when they began to capture most Congress seats and many more others.

\section{Concluding Remarks}

The 2016 American Presidential Election has come and gone and Donald Trump has won Hillary Clinton and two other presidential candidates through the votes from the United States Electoral Colleges. No matter what ever explanations that comes is aftermath. The Democrats will forever be analyzing the outrageous victory of Donald Trump over Hillary ClintonHowever, one observation that the researchers could make from the 2016 Presidential election is that no political party in recent time in American Democracy is able to dominate the White House for more than two tenures and even where they do they never go beyond twelve years at most consecutively. Therefore, blaming the victory of Donald Trump Presidential electoral victory on the failure and mistake committed by the Democratic Party, Hillary Clinton's corruptive tendencies, email saga, and many others factors as revealed by this study are all very important from the perspective of human analysis but democracy in America is so well grounded and consolidated beyond the level where a single political party could continue to rule for so many terms and years consecutively. If it happens that one of the political parties in America is able to rule for more than two tenures of four years each and then continue to third tenure and possibly fourth tenure, America cannot be called as a democratic consolidated state any longer and then Huntington in Durotoye (2015)'s benchmark for measuring democratic consolidation has failed and we cannot by any standard say that American Democracy is still a consolidated democracy.

Lest we forget, Huntington in Durotoye (2015) says, a country's democracy is consolidated if new sets of elected persons preferably from different political party win election by defeating incumbent party or candidates and secondly, when same things happens again for the second time. Let us also add that democratic consolidation will be more strengthen if opposition party continue from time to time defeat incumbent party and it is not only for first and second time but continuous.Therefore, the dismantling of the Democrats from the United State Government on the $20^{\text {th }}$ January, 2017 following the Presidential election victory of the Republican Party under the candidacy of Donald Trump on the $8^{\text {th }}$ November, 2016 is a battle axe of the unbendable power of a consolidated democracy in the United States not on the factors that were adduced by different people and scholars as revealed by this study because where democratic consolidation has grown to a giant and flamboyant height like the United States of America, there will always be invisible and unseen hands that will forcefully push aside incumbent government from the government house.

In the course of the investigation into the previous literatures to exhume the relevant factors that aid Donald Trump victory in the 2016 Presidential election in the great United States of America, the Researchers excavated some documents that revealed striking information about Donald Trump, the winner of the 2016 presidential election and current President of the United States of America. The revelations are: Can Trump be the first to go directly from Corner office to oval office? (Koran \& Browne, 2016), Donald Trump will be the only US president ever with no political or military experience (Crockett, 2016). Where Trump ranks among least experienced presidents (Yomtov, 2016), U.S presidents with the least prior political experience (WorldAtlas, 2016). The summary the researchers made from the above documents and others are that Donald Trump up till the date he won the presidential election he has never held any political position neither has he ever contest for any elective political post. He has never as well held any public administration position.

Though, whether Trump has ever held political position or not is not the onus of this study. Though, it is very necessary to bring out the revelation made because the Researchers assumed that the Democrats never take trump serious because to them Trump, a man that is coming from nowhere to nowhere can never be able to defeat Hillary Clinton, a woman with a cream of national and international public experience. Second reason why the revelation is necessary is because Donald Trump's total political inexperience has become a great concern to the most powerful nations in general and America in particular and has raised several questions as 
captured in the documents holding the revelations. In the light of the above, a research gap has been created based on this study which other researchers other than the present researchers would have to carry out. The Researchers of this study will have to help the new researchers to generate the research questions that their research will have to answer. The questions are why did the Americans voted into power a man that is a complete novice in political and public administration? How can Donald Trump rule America and the world with the high level of political and public administration inexperience he have if America will still be Americathe watchdog and police of the world?

\section{Reference}

[1]. Anderson, L.V. (2016). White Woman Sold out Sisterhood and the World by Voting for Trump. $\mathrm{CNN}$ in $\mathrm{XX}$ Factor. November 9. Available online at http://www.slate.com/blogs/xx_ factor/2016/11/09/ white_women_ sold_out_ the_sisterhood_and_the_world_by_voting_for_trump.html

[2]. Ball, K. (2016). The Democratic Party Deserved to Die. The Huffington Post. November 10. Available online at http://www .huffingtonpost.com/entry/the-democratic-party-deserves- to-die_us_58236ad5e4b0aac62488cde5

[3]. Barrington, R. (2016). Trump won because Voters believed the System was Corrupt. They were right. The Telegraph. UK. November 9. Available online at http://www.telegraph.co.uk/news/2016/11/09/trump-won-because-voters-believed-the-systemwas-corrupt-they-we/

[4]. Berman, A. (2016). Voter turnout in Wisconsin at lowest level in 20 years and down $15 \%$ in Milwankee, where $70 \%$ black voters live. Ariberman. November $10 . \quad$ https://twitter.com/AriBerman/status/796757974177943552

[5]. Cardillo, J. (2016). Trump Won Because He Listened to the American People. It is Really that Simple. Available online at http://ijr.com/opinion/2016/11/261809-trump-won-listened-american-people-really-simple/

[6]. Camosy, C.C. (2016). Trump Won because college-educated Americans are out of touch. Despatch News. Alaska Available online at https://www.adn.com/opinions/national-opinions/2016/11/09/trump-won-because-college-educated-americans-are-out-oftouch/

[7]. Crockett, Z. (2016). Donald Trump will be the only US president ever with no political or military experience. Vox. November 11. Available online at http://www.vox.com/policy-and-politics/2016/11/11/13587532/donald-trump-no-experience

[8]. Durotoye, A. (2015). Nigeria's 2015 Presidential Election: between Democratic Consolidation and Change. European Scientific Journal. Vol.11, No 19. July 2015. Pp 169-184. Available online at http://eujournal. org/index. php/esj/article/ viewFile /5936/5721

[9]. Fahrenthold, D.A. (2016). Trump recorded having extremely lewd Conversation about Women in 2005. October 8. Available online athttps://www.washingtonpost.com/politics/trump-recorded-having-extremely-lewd-conversation-about-women-in2005/2016/10/07/ 3b9ce776-8cb4-11e6-bf8a-3d26847eeed4_story.html?utm_term=.fa448cae0619

[10]. Filipov, D \& Roth, A. (2016). Moscow had contacts with Trump Team during Campaiign, RussianDiplomatsays. The Washington Post. November 10. Available online at https://www.washingtonpost.com/world/moscow-had-contacts-with-trump-team-duringcampaign-russian-diplomat-says/2016/11/10/28fb82fa-a73d-11e6-9bd184ab22d218e_story.html?tid=sm_tw\&utm_ 7303305 b6606

[11]. Guaghan, A.J. (2016). Donald Trump won the Presidency because Celebrity beats substance. Quartz. Available online at http://qz.com/832830/election-2016-how-did-donald-trump-win/

[12]. Isreal News. (2016). How did Trump Win? Here are 24 Theories. Available online at How did Trump Win? Here are 24 Theories. https://1israelnews.com/how-did-trump-win-here-are-24-theories/

[13]. Horwitz, S. (2016). Hillary Clinton email investigation: The FBI's Letter explaining its decision in full. Independent. October 30. Available online at http://www.independent.co.uk/news/world/americas/us-elections/hillary-clinton-email- investigationread-the-fbis-letter-in-full-a7387621.html

[14]. Imgur (2016). I made a Chart showing the popular votes turn out in 2008, 2012 and 2016. Availableonlineat http://imgur. com/ TOGIbcP

[15]. Kenya News. (2016). How did Trump win? Here are 24 theories. November 11. Available onlineat https://1newskenya. com/howdid-trump-win-here-are-24-theories/

[16]. Katz, J. (2016). Who will be President? The New York Times. Available online athttp://www. nytimes. com/interactive/ 2016/upshot/presidential-pollsforecast.html?rref=collection\%2Fsectioncollection\%2Fup shot\&action=cli ck\&content Collection=upshot\&region=rank\&module=package\&version=highlights\&contentPlacement=2\&pgtype=sectionfront \&_r=0

[17]. Katz, M. (2016). Trump Won because Democrats have lost Touch with the Working Class. In These Time. November 9. Avilable online at http://inthesetimes.com/article/19615/trump-won-because- democrats-have-lost-touch-with-the-working-class

[18]. Koran , L. \& Browne, R. (2016). Can Trump be the first to go directly from corner office to oval office? CNN Politics. August 12. Available online at http://edition.cnn.com/2016/08/11/politics/donald-trump-businessmen-presidents-history/

[19]. Kreig, G. (2016). How did Trump Win? Here are 24 Theories. CNN Politics. Available online at http://edition.cnn.com/2016/11/10/politics/why-donald-trump-won/

[20]. Krakauer, S. (2016). Donald Trump won because Americans are Biased Against Washington. The Resurgents. November 9. Available online at http://theresurgent.com/donald-trump-won-because-americans-are- biased-against-washington/

[21]. Kmc Forum (General Discussion). (2016). How did Trump Win? Here are 24 Theories. November 10. Available online at http://www.killermovies.com/forums/archive/index.php/t-636371-how-did-trump-win- here-are-24-theories.html

[22]. Lerner, M. (2016). Stop ShamingTrump Supporters. The New York Times. Available online at http://www.nytimes. com/interactive/projects/cp/opinion/election-night-2016/stop- shaming-trump-supporters

[23]. Mayring, P. (2000). Forum: Qualitative Social Research. Vol. 1, No. 2. Available online at http://www.qualitative research.net/index. php/fqs/article/viewArticle/1089/2385

[24]. Most Viral New Zealand Buzz. (2016). How did Trump Win? Here are 24 Theories. Available online athttp://nzbuzz.ga / news/ How- did-Trump-win?-Here-are-24-theories/

[25]. Mohen, I. (2016). Millenials aren't to blame this time. The Boston Globe. November 9. Availableonlineat https://www. bostonglobe. com/business/2016/11/09/millennials-aren- blame-this-time/PFx1FX25a8Pv7aVFy77UuK/story.html

[26]. Norcross, A. (2016) in USA-4-Americans. How did Trump Win? Here are 24 Theories.December 7. http://usaforamericans.com/how-did-trump-win-here-are-24-theories/

[27]. Politico. (2016). 2016 Presidential Elections Result. Available online at http://www.politico.com/2016election/results/map/president 
[28]. Potts, M. (2016). Donald Trump Won on White-Male Resentment but Don't Confuse that with the Working Class. The Nation. November 10. Available online at https://www.thenation.com/article/donald-trump-won-on-white-male-resentment-but-dontconfuse-that-with-the-working-class/

[29]. Read, M. (2016). Donald Trump Won because of Facebook. Select All. Available online at http://nymag.com/ selectall/2016/11 /donald-trump-won-because-of-facebook.html

[30]. Soave, R. (2016). Trump Won because of leftist Political Correctness Inspired a Terrifying Backlash.Reasons.com. Available online at http://reason.com/blog/2016/11/09/trump- won-because-leftist-political-corr

[31]. Soave, R. (2016). How political Correctness caused College Students to Cheer for Trump. Available on http://reason. com/blog/2016/02/23/how-political-correctness-caused-college

[32]. US Electoral College . What is the electoral College? .National Achieves and RecordsAdministration. Available online at https://www.archives.gov/federal-register/electoral-college/about.html

[33]. Talukdar, S. (2016). Trump Won because he remembered 'forgotten men, women' of US unlike Clinton. First Post. November 10. Available online at http://www.firstpost.com/world/trump-won-because-he-remembered-forgotten-men-women-of-us-unlikeclinton-3099276.html

[34]. Thiessen, M. (2016). Don't blame Comey for Clinton's defeat. The Washington Post. November $10 . \quad$ Available online at https://www.washingtonpost.com/blogs/post- partisan/wp/2016/11/10/dont-blame-comey-for-clintonsdefeat/?utm_term=.dbdb842ea24d

[35]. Victor, J. (2016). Have we ever elected a president who has never before won an election?. Tweet.Availableonline https:// cdn0. vox- cdn.com/thumbor/bgnZUNu95aGlbnp0nhXniCqvWy8=/800x0/filters:no_upscale()/cdn0.vox-cdn.com/uploads/ chorus_asset/file/7450285/mainchart.png

[36]. Watson, P.J. (2016). FDR won because of radio, JFK won because of Television, Trump won because of social media. Pnson Planet. November 10. Available at https://twitter.com/PrisonPlanet/status/796711122158186496

[37]. WorldAtlas. (2016). U.S Presidents with the least prior political experience. Available at http://www.worldatlas.com/articles/us-presidents-with-the-least-prior-political-experience.html

[38]. World News. (2016). How did Trump Win? Here are 24 Theories. November 10. Available online at https://article.wn. com/ view/2016/11/10/How_did_Trump_win_Here_are_24_theories_5/

[39]. Yomtov, J. (2016). Where Trump ranks among least experienced presidents. USA Today. November 11. Available online at http://www.usatoday.com/story/news/politics/onpolitics/2016/11/08/donald-trump-experience-president/93504134/ 